\title{
Conservation in Bale Mountains National Park, Ethiopia
}

\author{
Jesse C. Hillman
}

\begin{abstract}
Ethiopia does not often receive publicity for its wildlife conservation work, but there have been a commendable number of achievements over the last 15 years or so. For the last two years the author has been carrying out ecological studies to formulate management plans in the Bale Mountains area, which is in the process of being established as a national park. As a result of the developments and protection already afforded, numbers of the endemic mountain nyala have increased considerably.
\end{abstract}

The Bale Mountains National Park in south-east Ethiopia (Figure 1) was first proposed in the 1960 s, by the late Dr Leslie Brown and Mr John Blower, in order to conserve the endemic mountain nyala* and Simien fox within an area of great natural beauty. In 1970 a warden and staff were appointed, and in the intervening years several developments have occurred and various buildings constructed. Large numbers of mountain nyala can easily be seen, as well as good numbers of Simien fox, for which the Ethiopian Wildlife Conservation Organisation deserves great credit. In late 1983 a project was initiated to formulate management plans for the future development of the Park and to integrate conservation efforts with human use in and around the Park area. This project is funded by Wildlife Conservation International of the New York Zoological Society, under the auspices of the Ethiopian Wildlife Conservation Organisation. It has resulted in management plans for the area (Hillman, 1985), and an international workshop was held in the Park in October 1985. More detailed obser-

*The scientific names of species mentioned in the text are given in Table 1. vations on the ecology of the area will be published in the future.

Although the Park has yet to be gazetted, headquarters have been built in the north of the Park at Dinsho (Figure 2), and most conservation efforts are concentrated there. The proposed Park lies $400 \mathrm{~km}$ south-east of Addis Ababa, the capital, and covers $2200 \mathrm{sq} \mathrm{km}$. It consists of three main zones-the southern Harenna forest between $1600 \mathrm{~m}$ and $3500 \mathrm{~m}$ above sea level, the central Sanetti plateau and peaks area between $3500 \mathrm{~m}$ and $4400 \mathrm{~m}$, and the northern Gaysay/Adelay forest and grassland area between $3000 \mathrm{~m}$ and $3500 \mathrm{~m}$. Tullu Deemtu, at $4377 \mathrm{~m}$, is the second highest peak in Ethiopia.

The Park seeks to conserve the largest area of Afro-alpine habitat on the continent, which is also the water catchment area for three of Ethiopia's larger rivers. The little-known Harenna forest is a reasonable and representative area of moist tropical forest, dominated by Podocarpus gracilior, which has long been isolated from other similar forest areas by the Rift Valley and surrounding low-lying arid habitat. Important species that occur in the Bale Mountains National Park area are the endemic mountain nyala, Simien fox and giant mole rat, and the endemic subspecies Menelik's bushbuck; there is also an endemic subspecies of rock hyrax (Corbet, 1979). There are 11 endemic mammal species, of which eight are rodents; these 11 species represent 52 percent of the 21 endemic mammals of Ethiopia (Dieterlen and Rupp, 1978; Dorst, 1972; Petter, 1972; Yalden, 1975, 1985; Yalden et al., 1976, 1980, 1984). Of Ethiopia's 23 endemic bird species, 14 occur in the Park (Urban 


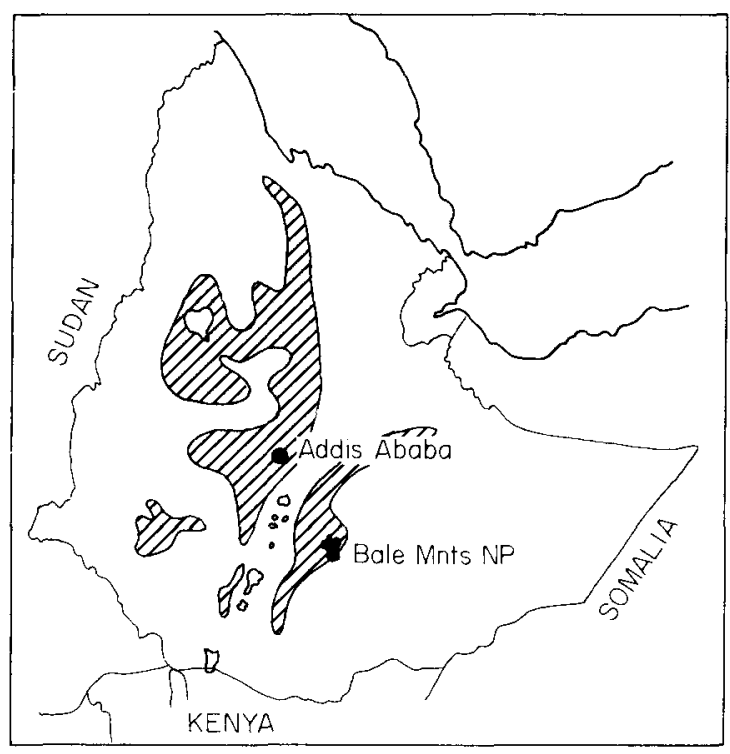

Figure 1. Map showing the position of Bale Mountains National Park in Ethiopia. Main highland areas $(>2500 \mathrm{~m}$ ASL) are shaded.

and Brown, 1971). Despite the altitude, cold nights and very cold water, amphibians are present. These include several peculiarities such as tree frogs (Leptopelis sp.), which live at or above the tree line (Largen, 1977), and the tiny 'earless toad' Nectophrynoides malcomi (Grandison, 1978). The high level of endemism probably results from the long isolation of the highlands of Ethiopia from other highland areas of the world; Yalden (1983) postulates that the very large area of high land in Ethiopia is the reason for the high rate of endemicity.

Other fauna include bohor reedbuck, grey duiker, klipspringer, warthog, bushpig, leopard, lion, serval cat and civet. The mountains are an important feeding area for passage and overwintering Palaearctic bird migrants-particularly waders, waterfowl and large raptors.

The results of the protection already afforded in Bale Mountains National Park are nothing less than spectacular as far as the mountain nyala are concerned. This striking Tragelaphine antelope is found only in the horseshoe-shaped eastern highlands of Ethiopia, between Harer in the north and Bale in the south (Yalden, et al., 1984). The species was only brought to the notice of western 90 scientists in 1910 , and since that time its range and numbers have been considerably diminished by human activity. Isolated populations still occur on the highest points of the eastern highlands, but the Bale population is the best remaining and is well protected. In the early 1970 s, when protection first began, small scattered groups of mountain nyala were periodically seen, which were obviously very afraid of man. Between five and 15 animals per month were seen at Gaysay near the headquarters. Now, 15 years later, the highest number seen on the monthly census of a 17 -sq$\mathrm{km}$ area at Gaysay is 555 different animals in a 3-hour period. Groups of up to 95 animals have been seen and are approachable by vehicle.

It is evident that the lower reaches of the mountains, at around $3000 \mathrm{~m}$, in the ecotone between the lower edge of the Juniper/Hagenia woodlands and the riverine grasslands, are more suited to the species than the upper lessvegetated areas. In most parts of their range, this habitat has been taken over for cultivation and pastoralism. The density of the mountain nyala seen at Gaysay cannot, unfortunately, be taken as representative of the whole Park area. The Harenna forest is a totally unsuitable habitat for the species, and numbers on the Sanetti plateau and central peak area are very low. A brief aerial survey of all other probable mountain nyala habitat has suggested that numbers in other mountain-top areas are similarly low, though reports from sport hunters in the forested Chercher, Din-din, Kunie and Muktar areas suggest that reasonable numbers may still occur there.

It is not possible at this stage to estimate the mountain nyala population size accurately. Dr Brown estimated the total population as 7000 8000 in the 1960s (Brown, 1969), with 85 percent of these in Bale. In most parts of the species's range, human pressures have increased in the intervening 15 years. It is likely, therefore, that numbers have decreased, and this opinion is supported by sport hunters who have known the area for a long period of time. The situation in Bale is difficult to assess, but I suspect that the population lies between 1250 and 1400 in the Park, a possible total of 2000-2500 in the whole Bale massif (including the Park), and a world Oryx Vol 20 No 2. April 1986 


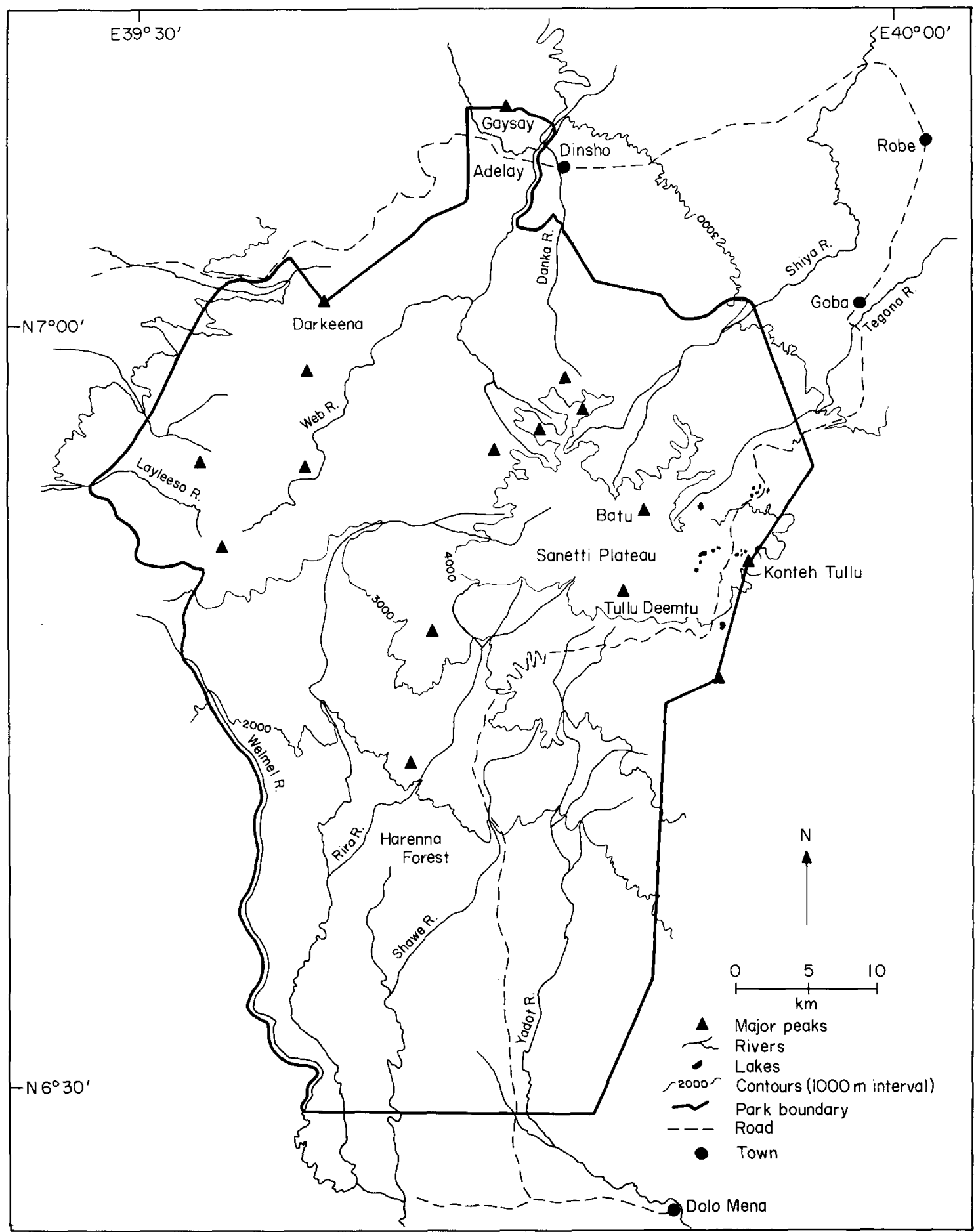

Figure 2. Bale Mountains National Park and its principal features. 
population of fewer than 5000 animals. The great majority of the animals in the Park are in the Gaysay/Adelay area. It is evident that such a concentration of animals in such a small area is not a healthy situation. The Ethiopian Wildlife Conservation Organisation has already identified a second mountain nyala conservation area, and more of the optimal lower altitude habitat will be added to Bale Mountains National Park. There are no mountain nyala in captivity anywhere in the world.

Simien fox occur mainly on the Sanetti plateau and in the broader high valleys of the central peak area of the Park. One pair is regularly seen down in the Gaysay grasslands in the dry season, presumably since the grass is shorter at this time, making rodent hunting easier (Malcolm, 1976). Simien fox occur on both sides of the Rift Valley; the main strongholds are in the Simien and Bale mountains, but in the past they were found in a few other areas between (Yalden et al., 1980). The species is supported by the vast numbers of rodents on the Sanetti plateau, with representatives of at least 11 species (Dieterlen and Rupp, 1978; Dorst, 1972; Petter, 1972; Yalden, 1973; Yalden et al., 1976). Numbers are reasonable, and would appear to be higher than the estimates of 350-475 made by Morris and Malcolm (1977). My current estimate of 700 Simien fox in the entire Park probably results from increased knowledge of the area and possibly an increase in the species's numbers. The best habitat is the Sanetti plateau, and five to 15 are usually seen on each trip across the $40 \mathrm{~km}$ of road that cross it. Elsewhere in the central peak area, a few occur in each valley. The population in the upper Web valley, west of the peaks, appears similar to the estimate given by Malcolm (1976), though human activity has increased. The road mentioned above was completed across the plateau in 1977 and may carry up to 100 lorries a day. It is the highest all-weather road in Africa, crossing the $4000 \mathrm{~m}$ contour. Unfortunately, some drivers are still influenced by the superstition that any canid crossing their path must be killed to avert bad luck. Two have been shot and one run over that we know of, and several other skeletons have been found in the area. An education programme on this and other human-associated problems has already been initiated.

92
A Simien fox den was observed for a 3-month period beginning soon after the cubs' birth. It was evident that more than two fox adults were responsible for their care, and up to five adult and near-adult foxes were seen at the den on different occasions. On the plateau Simien fox are primarily seen alone, though often two or three are seen in reasonably close proximity, and we have seen seven in one group on more than one occasion.

The giant mole rat has been little studied in the past (Yalden, 1975). Brought to science's attention in the nineteenth century by Ruppell, little was known about the species until the last 15

Table 1. Scientific names of animals in the text

$\begin{array}{ll}\begin{array}{ll}\text { Mammals } \\ \text { Bushbuck, Menelik's }\end{array} & \begin{array}{l}\text { Tragelaphus scriptus meneliki } \\ \text { Neumann }\end{array} \\ \text { Bushpig } & \text { Potamochoerus porcus (Linn.) } \\ \text { Civet } & \text { Viverra civetta Schreber } \\ \text { Duiker, grey } & \text { Sylvicapra grimmia (Linn.) } \\ \text { Fox, Simien } & \text { Canis simensis Ruppell } \\ \text { Hare } & \text { Lepus starki Petter } \\ \text { Hartebeest. Swayne's Alcelaphus buselaphus swaynei } & \text { (Sclater) } \\ \text { Hyrax, rock } & \text { Procavia capensis capillosa Brauer } \\ \text { Klipspringer } & \text { Oreotragus oreotragus (Zimmermann) } \\ \text { Leopard } & \text { Felis pardus Linn. } \\ \text { Lion } & \text { Felis leo Linn. } \\ \text { Molerat, giant } & \text { Tachyoryctes macrocephalus } \\ & \text { (Ruppell) } \\ \text { Nyala, mountain } & \text { Tragelaphus buxtoni (Lydekker) } \\ \text { Reedbuck, Bohor } & \text { Redunca redunca (Pallas) } \\ \text { Serval } & \text { Felis serval Schreber } \\ \text { Warthog } & \text { Phacochoenus aethiopicus (Pallas) }\end{array}$

Birds

Bee-eater, European Merops apiaster Linn.

Buzzard, augur

Crane, Wattled

Buteo rufofuscus (Forster)

Eagle, steppe and

tawny

Grus carunculatus (Gmelin)

Eagle. Verrreaux's

Eagle-owl, cape

Harrier, marsh

Harrier, pallid

Kestrel

Owl, long-eared

Stork, black

Stork, white
Aquila rapax (Temminck)

Aquila verreauxii Lesson

Bubo capensis Smith

Circus aeruginosus (Linn.)

Circus macrourus (Gmelin)

Falco tinnunculus Linn.

Asio otus Linn.

Ciconia nigra (Linn.)

Ciconia ciconia (Linn.) 


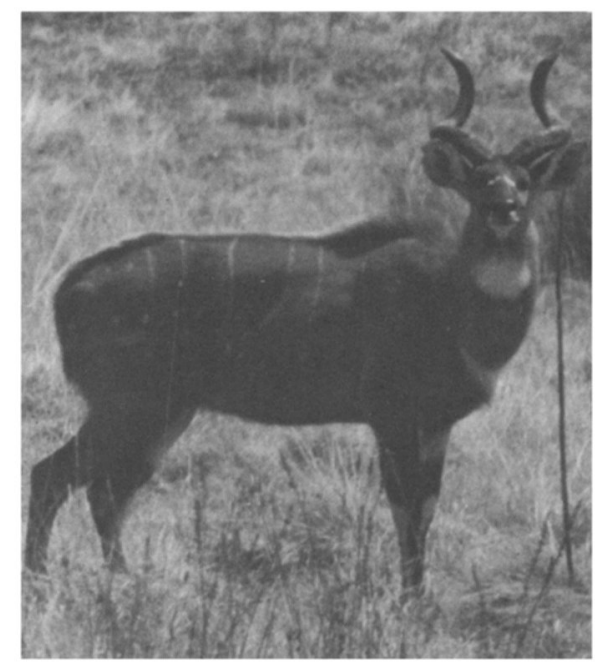

Above: Adult male mountain nyala.

Right: Mountain nyala, an adult female and a female yearling (J.C. Hillman).

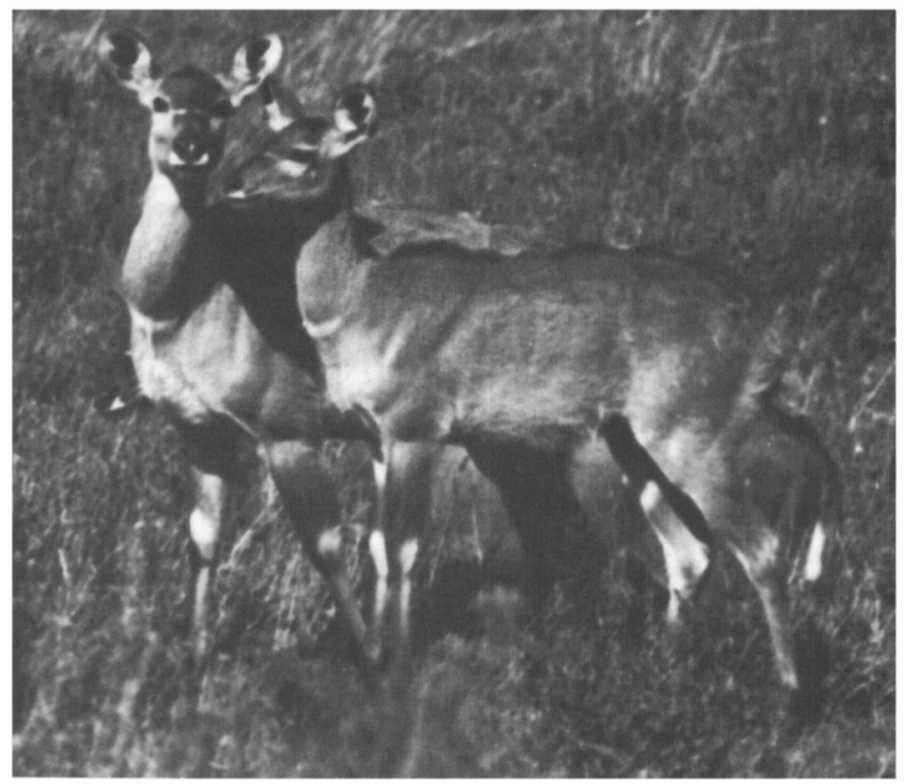

years. A detailed study now being carried out by a University of Addis Ababa student, Shimelis Bayene, should increase our knowledge of the role this creature plays in the ecology of the plateau. It weighs nearly $1 \mathrm{~kg}$ and gathers most of its food above ground from around numerous burrow entrances. The tunnelling activities of this rodent species in particular give the plateau area the appearance of a badly ploughed field. This activity, together with the extreme cold and exposure, has definite effects on the vegetation of the area, reducing it to sparse scattered clumps of small herbs and grasses. This mole rat and the other rodents, together with a hare, are an important food source for the Simien fox, and for the large numbers of birds of prey. Several European raptors over-winter in the Bale mountains, including the steppe eagle, marsh harrier, pallid harrier and kestrel, while local residents include Verreaux's eagle, tawny eagle, augur buzzard, long-eared owl and cape eagle-owl.

Additional over-wintering bird migrants include many waterfowl and wader species, which find suitable habitat in the numerous small lakes on the Sanetti plateau. Some passage migrants, including the European white stork, European black stork and European bee-eater, pass through the area. The Sanetti plateau is an important breeding site of the wattled crane, at least four pairs of which reside there. Many of the 14 endemic Ethiopian bird species that occur in the Bale Mountains National Park have been recorded breeding there.

The proposed Bale Mountains National Park plays an important role on the African continent in conserving this unusual habitat. Human pressures on the area are not too great, except in the lower-lying montain nyala habitat near Dinsho. Elsewhere in the mountains some nomadic pastoralism exists, linked to the periodic use of important mineral springs above $4000 \mathrm{~m}$ in the central peaks by cattle from areas surrounding the Park. Forest products are in demand-chiefly firewood and construction timber from the northern fringing woodlands, and bamboo from Harenna. A new sawmill has been constructed south of the Harenna forest, but is confining its activities to areas outside the Park. In most dry seasons, large fires are set in the giant heather belt that rings the mountains between $3500 \mathrm{~m}$ and $4000 \mathrm{~m}$ to provide a brief flush of green grass and herbs. This is now being done to provide a source 
of fuel, from the standing dead heather stems that remain, for the burgeoning urban centres that lie close to the Park's northern boundaries. Regulation of this activity will have to be imposed in the very near future.

Regulation of human activities is the keyword, not exclusion. Any attempt to exclude these activities totally would only alienate the Park from its surroundings and from local administration. Education work is an important function of the project and Park staff, and is proving successful in explaining the role of the Park in the conservation of the environment and natural resources, especially water catchment and forests. The wildlife is seen as part of Ethiopia's rich natural heritage, worthy of conservation in its own right, and regional and national pride in the area is on the increase. Tourism is not yet very important, but it is increasing and could generate a significant amount of foreign exchange and contribute to the Park's upkeep and development. With respect to environmental education, field courses are conducted by project and Park staff for wildlife, forestry and university students, and information is disseminated to visiting schools and local and foreign students.

Ethiopia is mentioned only sporadically in the conservation press. The determined and continuing conservation work in the country has met with several successes, not only in Bale Mountains, but with respect to Swayne's hartebeest, for example (Bolton, 1971, 1973; Berhanu, 1974; Lewis and Wilson, 1977; Lewis, 1982; Kassaye and Messana, 1984). Despite extremely difficult conditions, conservation is actively carried out, and for this the Ethiopian Government, and the Wildlife Conservation Organisation in particular, deserve recognition. International aid to the Ethiopian Wildlife Conservation Organisation has been almost nonexistent, yet their achievements are highly commendable.

\section{References}

Berhanu, L. 1974. Operation Swayne's Hartebeest. Oryx. 12, 556-558.

Bolton. M. 1971. Ethiopia. last chance for Swayne's hartebeest. Biol. Cons. 3, 2

Bolton. M. 1973. Hartebeest in Ethiopia. Oryx, 12,99-108. Brown. L.H. 1969. Observations on the status, habitat and behaviour of the Mountain Nyala Tragelaphus buxtoni in Ethiopia. Mammalia, 33.545-597.

Corbet, G.B. 1979. The taxonomy of Procavia capensis in Ethiopia, with special reference to the aberrant tusks of $P$. c. capillosa Brauer (Mammalia, Hyracoidea). Bull. Br Mus. nat. Hist. (Zool.). 36, 251-259.

Dieterlen, F. and Rupp, H. 1978. Megadendromus nikolausi, Gen. nov., sp. nov. (Dendromurinae: Rodentia), ein neuer Nager aus Athiopien. Zeitschrift. F. Saugetierkunde, 43, 129-192.

Dorst. J. 1972. Notes sur quelques rongeurs observes en Ethiopie. Mammalia, 36, 182-192.

Grandison, A.G.C. 1978. The Occurrence of Nectophrynoides (Anura Bufonidae) in Ethiopia. A new concept of the genus with a description of a new species. Monit. zool. ital. NS Suppl. XI (6), 119-172.

Hillman, J.C. 1985. Bale Mountains National Park: Management Plans. Wildlife Conservation International, New York Zoological Society.

Kassaye, F. and Messana G.G. 1984. Report to Ethiopia's Wildlife Conservation Organisation on the Sanctuary of Senkele and Swayne's Hartebeest. Mimeo.

Largen, M.J. 1977. The status of the genus Leptopelis (Amphibia Anura Hyperolidae) in Ethiopia, including descriptions of two new species. Monit. zool. ital. NS Suppl. IX (5), 85-136.

Lewis, J.G. 1982. A brief report on Swayne's Hartebeest of the Senkele plains, Ethiopia. WCO, Addis Ababa. Mimeo.

Lewis, J.G. and Wilson, R.T. 1977. The Plight of Swayne's Hartebeest. Oryx, 13, 490-494.

Malcolm, J.R. 1976. A survey of the Simien foxes (Canis simensis) in the Bale Mountains. Mimeo.

Morris, P.A. and Malcolm, J.R. (1977) The Simien Fox in the Bale Mountains. Oryx, 14, 151-160.

Petter, F. 1972. Deux rongeurs nouveaux d'Ethiopie: Stenocephalemys griseicauda sp. nov. et Lophuromys melanonyx sp. nov. Mammalia, 36, 171-181.

Urban, E.K. and Brown, L.H. 1971. A Checklist of the Birds of Ethiopia. Haile Selassie I University Press, Addis Ababa.

Yalden. D.W. 1973. Prey of the Abyssinian long-eared owl Asio abyssinicus. lbis, 115, 605-606.

Yalden, D.W. 1975. Some observations on the giant mole-rat Tachyoryctes macrocephalus (Ruppell 1842) (Mammalia Rhizomyidae) of Ethiopia. Monit. zool. ital. NS Suppl. VI, 275-303.

Yalden. D.W. 1983. The extent of high ground in Ethiopia compared to the rest of Africa. Sinet (Eth. J. of Science), 6 , $35-40$.

Yalden, D.W. 1985. Tachyoryctes macrocephalus. Mammalian Species, 237, 1-3.

Yalden, D.W., Largen, M.J. and Kock, D. 1976. Catalogue of the mammals of Ethiopia. 2. Insectivora and Rodentia. Monit. zool. ital. NS Suppl. VIII, $1-118$.

Yalden, D.W., Largen, M.J. and Kock, D. 1980. Catalogue of the mammals of Ethiopia. 4. Carnivora. Monit. zool. ital. NS Suppl. XIII (8), 169-272.

Yalden, D.W., Largen, M.J. and Kock, D. 1984. Catalogue of the mammals of Ethiopia. 5. Artiodactyla. Monit. zool. ital. NS Suppl. XIX (4), 67-221.

Dr Jesse C. Hillman, c/o Wildlife Conservation Organisation. PO Box 386, Addis Ababa, Ethiopia. 